\title{
INFLUENCE OF THE TIME/TEMPERATURE BINOMIAL ON THE HYDROXYMETHYLFURFURAL CONTENT OF FLORAL HONEYS SUBJECTED TO HEAT TREATMENT
}

\author{
Influência do binômio tempo e temperatura nos teores de \\ hidroximetilfurfural em méis florais submetidos ao aquecimento
}

\author{
Roberta de Oliveira Resende Ribeiro' ${ }^{1}$ Carla da Silva Carneiro², Eliane Teixeira Mársico ${ }^{3}$, \\ Fernanda Lima Cunha ${ }^{1}$, Carlos Adam Conte Junior ${ }^{3}$, Sérgio Borges Mano ${ }^{3}$
}

\begin{abstract}
Hydroxymethylfurfural (HMF) content is internationally recognized for its ability to indicate the freshness or lack of freshness of honey and can be used to judge the processing and storage condition of honey. The objective of the present study was to evaluate the evolution of HMF levels in fresh extracted honeys submitted to different temperatures ranging from 30 to $100^{\circ} \mathrm{C}$, during pre-established time intervals $(30,45,60,180$ and 720 minutes).The test was conducted in floral honey with an initial HMF content of $2.2 \mathrm{mg} / \mathrm{Kg}$. The maximum value recommended by the Brazilian law $(60 \mathrm{mg} / \mathrm{Kg})$ was not exceeded in the samples subjected to heating for 30, 45 and 60 minutes regardless of the temperatures used. When the samples were heat treated during 180 minutes at $90^{\circ} \mathrm{C}$ the official value was surpassed. The highest values were observed in samples subjected to heating over 720 minutes, and the limit was exceeded at $70^{\circ} \mathrm{C}$. The results obtained indicate that the $\mathrm{HMF}$ content gradually increases when the honey is heated at high temperatures for long periods. Therefore, we suggest a process optimization, considering the initial HMF content of the product and standardizing times and temperatures to ensure a good quality of the final product.
\end{abstract}

Index terms: Honey quality, HMF, heating.

\section{RESUMO}

O teor de hidroximetilfurfural (HMF) é reconhecido internacionalmente pela capacidade de indicar o frescor do mel, podendo ser usado para avaliar o processamento e condições de armazenamento do mel. Neste trabalho objetivou-se avaliar a evolução dos níveis de HMF em mel recém-obtido, submetidas a diferentes temperaturas que variaram de 30 a $100^{\circ} \mathrm{C}$, por intervalos de tempo prédefinidos (30, 45, 60, 180 e 720 minutos). O ensaio foi realizado em mel floral, cujo valor inicial de HMF foi de $2,2 \mathrm{mg} / \mathrm{Kg}$. O valor máximo preconizado pela legislação brasileira não foi ultrapassado nas amostras submetidas ao aquecimento por 30,45 e 60 minutos independente das temperaturas. Por um período de 180 minutos, o limite legal de $60 \mathrm{mg} / \mathrm{Kg}$ foi extrapolado nas amostras tratadas a $90^{\circ} \mathrm{C}$. Os valores mais elevados foram observados nas amostras submetidas ao aquecimento por 720 minutos, tendo o limite legal ultrapassado em temperatura mais branda $\left(70^{\circ} \mathrm{C}\right)$. Com base nos resultados obtidos, pôde-se concluir que o conteúdo de HMF aumenta gradativamente quando o mel é exposto a altas temperaturas, por tempo prolongado. Sendo assim, sugere-se uma otimização nos processos de beneficiamento, considerando a quantidade inicial de HMF no produto, com processamento padronizado em temperaturas e tempo controlados para garantia da qualidade do produto final.

Termos para indexação: Qualidade do mel, HMF, aquecimento.

\section{(Received in january 18, 2012 and approved in april 23, 2012)}

\section{INTRODUCTION}

Honey is a natural product that must be delivered to the consumer with its essential composition and its quality minimally altered (CODEX, 1987). However, honey suffers a natural ageing process which starts on the field when it is harvested and placed in barrels by the beekeepers; it goes on with transport and storage previous to the industrial treatment and continues during the industrial process and even after it (SANCHO et al., 1992). 5-hydroxyimethylfurfural (HMF) is a furanic compound produced by sugar degradation (RAMIREZ et al., 2000), naturally formed as an intermediate in the Maillard Reaction (AMES, 1992) or from dehydration of hexoses in acid medium (BELITZ; GROSCH, 1999), mainly products with $\mathrm{pH}$ value up to 5.0 (DAMODARAN et al., 2010). The presence of simple sugars and water in acid medium favors the formation of this furanic compound (NOZAL et al., 2001).

1Universidade Federal Fluminense /UFF - Programa de Pós-Graduação em Higiene Veterinária e Processamento Tecnológico de Produtos de Origem Animal - 24230-340 - Niterói, RJ - Brasil

${ }^{2}$ Universidade Federal Fluminense /UFF - Programa de Pós-Graduação em Higiene Veterinária e Processamento Tecnológico de Produtos de Origem Animal -24230-340 - Niterói, RJ - Brasil - carlavet.s@gmail.com

${ }^{3}$ Universidade Federal Fluminense /UFF - Departamento de Tecnologia de Alimentos - Niterói - Faculdade de Veterinária - RJ - Brasil

Ciênc. agrotec., Lavras, v. 36, n. 2, p. 204 -209, mar./abr., 2012 
HMF formation process can be accelerated during the heat treatments applied to honey (KROH, 1994). However, in acid media, HMF can be formed even at low temperatures (LEE; NAGY, 1990), which explains the gradual increase of HMF levels during storage. Some factors, such as the use of metallic containers (WHITE, 1979), honey physico-chemical properties $(\mathrm{pH}$, total acidity, mineral content), the floral origin (AANAM; DART, 1995) and the thermal stress to which the product is subjected in the hive (SPANO et al., 2006), directly influence HMF formation during storage. Due to the factors above mentioned, HMF is considered one of the degradation products more frequently used as honey quality indicator (TOSI et al., 2002; FALLICO et al., 2004), once this product is almost absent in fresh extracted honeys and its concentration increases with time (SPANO et al., 2006), inadequate exposure in retail outlets, aging and improper use of heat to make honey more liquid.

In recent decades, HMF has drawn the attention of the scientific community for its carcinogenic potential for humans. Some studies have shown that this metabolite can be converted in vivo to 5sulfooxymethylfurfural (SMF), a genotoxic compound (SURH et al., 1994). In addition, at high concentrations, HMF is cytotoxic, causing irritation to eyes, upper respiratory tract, skin and mucous membranes (ULBRICHT et al., 1984; BRUCE et al., 1993). For this reason, the Codex Alimentarius and the European Commission have set a maximum HMF level for honey of $40 \mathrm{mg} / \mathrm{Kg}$, except for honeys coming from tropical countries and honeys with low enzyme levels, the HMF limit of which was set in 80 and $15 \mathrm{mg} / \mathrm{Kg}$ respectively (CODEX, 1987; EUROPEAN COMMISSION, 2001). The Brazilian legislation recommends a maximum limit of 60 $\mathrm{mg} / \mathrm{Kg}$ for all kinds of honey (BRASIL, 2000). The amount of HMF detectable in honey is directly related to the intensity of the heat and the exposure time applied during processing.

The objective of the present study was to evaluate the evolution of HMF content in fresh extracted honeys, subjected to different temperatures ranging from 30 to $100^{\circ} \mathrm{C}$, over pre-established time intervals $(30,45,60,180$ and 720 minutes).

\section{MATERIALS AND METHODS}

\section{Honey samples}

Honey samples were directly obtained from an apiary located in the mountain region of Rio de Janeiro, in the municipality of Teresopolis, a region characterized by diverse vegetation with altitude tropical climate and average annual temperature of $16 \pm 2^{\circ} \mathrm{C}$. Approximately 6 $\mathrm{Kg}$ of multifloral honey were fractionated in 120 glass bottles with $20 \mathrm{~mL}$ capacity and stored at $20 \pm 1^{\circ} \mathrm{C}$.

\section{Treatments}

In order to evaluate the effects of time and temperature on the variation of HMF levels in the samples of floral honey, heat treatments were performed, in triplicate, by immersion in a thermostatic bath with periodic shaking, set at the following temperatures: 30, 40, 50, 60, 70, 80, 90 and $100^{\circ} \mathrm{C}$. During this stage, the samples were kept at those temperatures during 30,45, 60, 180 and 720 minutes. Temperature was monitored with a thermocouple introduced at the geometrical center of the bottles. The time was measured from the moment the temperature reached the value established in the methodology. Then, the samples were cooled by immersion in cold water at $4 \pm 2^{\circ} \mathrm{C}$ and immediately analyzed.

\section{Physico-chemical analysis}

The samples of honey were submitted to physicochemical analysis in order to verify their quality before undergoing heat treatment. The following techniques were used: determination of $\mathrm{pH}$, fixed mineral residue, insoluble matter, reducing and non-reducing sugars, Lund reaction, acidity analysis, Fiehe reaction.

\section{HMF content determination}

The content of HMF in the samples was determined by Winkler spectrophotometry method. Five grams of honey were weighted, dissolved in distilled water and transferred to a $25 \mathrm{~mL}$ volumetric flask and make up to the mark. Immediately after preparation a $2 \mathrm{~mL}$ aliquot was transferred to a test tube and $5 \mathrm{~mL}$ of $10 \%$ p-toluidin solution in isopropanol and $1 \mathrm{~mL}$ of $5 \%$ barbituric acid aqueous solution were added. In another test tube (reference) was added $2 \mathrm{~mL}$ of honey solution, $5 \mathrm{~mL}$ of $\mathrm{p}$ toluidin solution and $1 \mathrm{~mL}$ distilled water. The reagents were used in up to 2 minutes after preparation in order to ensure the stability of the solutions. The absorbance at $550 \mathrm{~nm}$ was determined using a spectrophotometer. The honey used contained an initial HMF value of $2.2 \mathrm{mg} / \mathrm{Kg}$ before heating.

\section{Statistical Analysis}

Data were statistically analyzed using the two-way analysis of variance (ANOVA), aiming at identifying differences in HMF content in honey caused by the interaction of time/temperature variables. Multiple 
regression was applied with HMF content as dependent variable and the sample immersion time in the hydrostatic bath and the temperature of the bath as independent variables. All the analyses were performed using a statistic package available in the market (GraphPad Prism version 5.00 for Windows, GraphPad Software, San Diego, California, USA).

\section{RESULTS AND DISCUSSION}

The values obtained during the experiment are presented in tables and figures that summarize the influence of the heat treatments on HMF content in the samples of floral honey analyzed. HMF content significantly varied $(\mathrm{P}<0.001)$ with the increase of temperature and immersion time to which the samples were subjected. The regression coefficient $(r=0.98)$, indicated that only $2 \%$ of the regression variances do not depend on the variables studied. It was observed that $\mathrm{HMF}$ content increases slowly up to $70^{\circ} \mathrm{C}$ and, above this temperature, its production rate increases in a more significant way, mainly at temperatures above $80^{\circ} \mathrm{C}$. The HMF content increase is more evident when the immersion time in the hydrostatic bath increases, reaching its highest value in the samples exposed to $100^{\circ} \mathrm{C}$ for 720 minutes, which presented an average value of $101.24 \mathrm{mg}$ / $\mathrm{Kg}$ (Figure 1).

The HMF content variation was small in the treatments at 30,40 and $50^{\circ} \mathrm{C}$ for up to 180 minutes, varying from $4.46 \mathrm{mg} / \mathrm{Kg}$ at $30^{\circ} \mathrm{C}$ during 30 minutes to $15.28 \mathrm{mg} / \mathrm{Kg}$ at $50^{\circ} \mathrm{C}$ for 180 minutes, indicating that the use of those temperatures in honeys with low initial HMF content does not cause a significant increase of this compound. In general, it can be observed that honeys heat treated at 40 and $50^{\circ} \mathrm{C}$ for up to 180 minutes does not present a significant difference of HMF formation $(\mathrm{P}<0.05)$. Karabournioti and Zervalaki (2001) reported a slightly significant increase of HMF content in orange honeys heat treated at $35^{\circ} \mathrm{C}, 45^{\circ} \mathrm{C}, 55^{\circ} \mathrm{C}$ and $65^{\circ} \mathrm{C}$ for 24 hours, from $2.25 \mathrm{mg} / \mathrm{Kg}$ (without heating) to $3.45,3.75,4.35$ and 19.00 $\mathrm{mg} / \mathrm{Kg}$, respectively and concluded that mild temperatures up to $55^{\circ} \mathrm{C}$, do not influence the increase of $\mathrm{HMF}$ regardless of the exposure time.

The effects of heating on HMF increase can be observed when the exposure time is longer, the time variable being the most significant factor in increasing $\mathrm{HMF}$ content, when temperatures between 30 and $90^{\circ} \mathrm{C}$ are considered. The results show that there was no significant difference ( $p>0.05)$ on HMF levels in samples submitted to temperatures of $30,40,50,60,70$ and $80^{\circ} \mathrm{C}$ for 30 minutes. The values increased from $2.2 \mathrm{mg} / \mathrm{Kg}$ (fresh extracted honey) to 4.46, 5.68, 6.96, 7.12, 8.88 and $10.68 \mathrm{mg} / \mathrm{Kg}$, respectively. Samples heated at 80,90 and $100^{\circ} \mathrm{C}$ for 30 minutes, significantly differed $(\mathrm{P}<0.05)$ from samples kept in thermostatic bath for 45 minutes confirming the trend of increased levels of HMF when the heating time increases (Table 1).

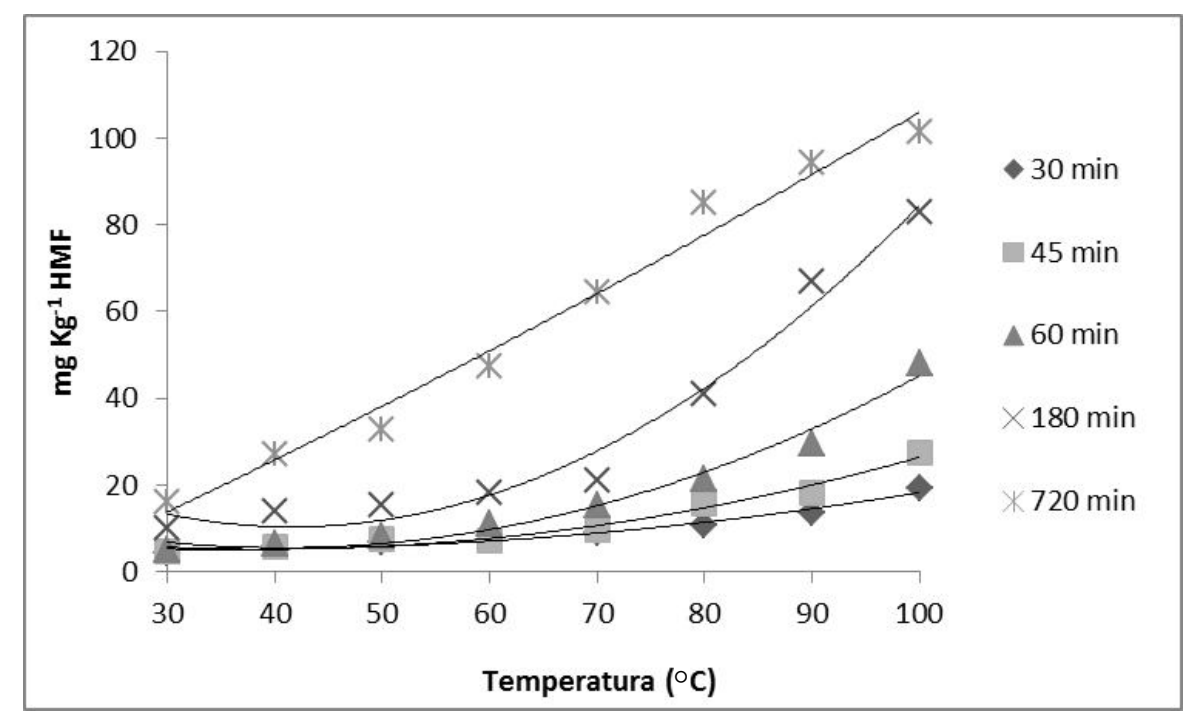

Figure 1 - Results of the determinations of HMF content according to temperature and time of immersion of honey samples. 
Table 1 - Variation of the concentration of Hydroxyimethylfurfural $(\mathrm{mg} / \mathrm{Kg})$ in honey samples as a function of temperature and time of immersion in a thermostatic bath.

\begin{tabular}{cccccc}
\hline \multirow{2}{*}{ Temperature } & \multicolumn{5}{l}{ Immersion time } \\
\cline { 2 - 6 } & $30 \mathrm{~min}$ & $45 \mathrm{~min}$ & $60 \mathrm{~min}$ & $180 \mathrm{~min}$ & $720 \mathrm{~min}$ \\
\hline $30^{\circ} \mathrm{C}$ & $4.46 \pm 0.15^{\mathrm{Aa}}$ & $4.77 \pm 0.12^{\mathrm{Aa}}$ & $5.04 \pm 0.90^{\mathrm{Aa}}$ & $9.97 \pm 0.43^{\mathrm{Ba}}$ & $16.18 \pm 0.37^{\mathrm{Ca}}$ \\
$40^{\circ} \mathrm{C}$ & $5.68 \pm 0.83^{\mathrm{Aa}}$ & $5.82 \pm 0.32^{\mathrm{Aa}}$ & $6.58 \pm 0.53^{\mathrm{Aa}}$ & $14.05 \pm 0.68^{\mathrm{Bb}}$ & $27.15 \pm 0.18^{\mathrm{Cb}}$ \\
$50^{\circ} \mathrm{C}$ & $6.96 \pm 0.13^{\mathrm{Aa}}$ & $7.39 \pm 0.22^{\mathrm{Aa}}$ & $8.18 \pm 0.14^{\mathrm{Aa}}$ & $15.28 \pm 0.80^{\mathrm{Bb}}$ & $32.63 \pm 0.37^{\mathrm{Cc}}$ \\
$60^{\circ} \mathrm{C}$ & $7.12 \pm 0.22^{\mathrm{Aa}}$ & $7.33 \pm 0.16^{\mathrm{Aa}}$ & $10.97 \pm 0.10^{\mathrm{Aa}}$ & $18.32 \pm 0.29^{\mathrm{Bb}}$ & $47.19 \pm 3.19^{\mathrm{Cd}}$ \\
$70^{\circ} \mathrm{C}$ & $8.88 \pm 0.37^{\mathrm{Aa}}$ & $9.61 \pm 0.43^{\mathrm{Aa}}$ & $15.24 \pm 0.19^{\mathrm{Bb}}$ & $20.96 \pm 0.11^{\mathrm{Cb}}$ & $64.37 \pm 0.11^{\mathrm{De}}$ \\
$80^{\circ} \mathrm{C}$ & $10.68 \pm 0.28^{\mathrm{Ab}}$ & $15.62 \pm 0.24^{\mathrm{Bb}}$ & $21.35 \pm 0.30^{\mathrm{Cc}}$ & $41.03 \pm 0.08^{\mathrm{Dc}}$ & $85.10 \pm 0.26^{\mathrm{Ef}}$ \\
$90^{\circ} \mathrm{C}$ & $13.54 \pm 1.10^{\mathrm{Ac}}$ & $18.36 \pm 0.24^{\mathrm{Bc}}$ & $29.55 \pm 0.30^{\mathrm{Cd}}$ & $66.96 \pm 0.28^{\mathrm{Dd}}$ & $94.23 \pm 0.56^{\mathrm{Eg}}$ \\
$100^{\circ} \mathrm{C}$ & $19.31 \pm 2.40^{\mathrm{Ad}}$ & $27.48 \pm 0.32^{\mathrm{Bd}}$ & $48.19 \pm 1.35^{\mathrm{Ce}}$ & $82.79 \pm 3.23^{\mathrm{De}}$ & $101.24 \pm 0.35^{\mathrm{Eh}}$ \\
\hline
\end{tabular}

The appearance of honey plays an important role on its commercial acceptance, once consumers demand a fluid, non-crystallized product. Fresh extracted honey is liquid. However, it may crystallize during storage at higher or lower speed depending on several factors such as origin (botanical and geographical), temperature, moisture content and sugar content (PIRO et al. 1996; BARTH; SINGH,1999). In order to delay the natural crystallization process and ensure stability during its shelf-life, fresh honey is usually submitted to heating before being packed, with the purpose of dissolving sugars and destroying yeasts (BATH; SINGH, 1999; TOSI et al., 2002). The results of the present study indicate that honey should be heated at mild temperatures, between $40^{\circ} \mathrm{C}$ and $50^{\circ} \mathrm{C}$, heat treatments above $90^{\circ} \mathrm{C}$ are not recommended.

According to Jeanne (1985) de-crystallization of finely crystallized honeys requires different times and temperatures, for example, it is recommended that a $20 \mathrm{Kg}$ recipient is heated at $40^{\circ} \mathrm{C}$ during 24 hours, and the author suggests a time/temperature binomial of $72 \mathrm{~h}$ at $50^{\circ} \mathrm{C}$ for a $300 \mathrm{Kg}$ recipient. However, the present study showed that high contents of HMF (2.15 and $32.63 \mathrm{mg} / \mathrm{Kg}$, for samples exposed to 40 and $50^{\circ} \mathrm{C}$, for 12 hours, respectively), can be obtained when heat treatments are applied during long periods. Although the maximum level of HMF was not exceeded at temperatures up to $50^{\circ} \mathrm{C}$, the value was close to that recommended by international legislation, which could limit the international trade of samples submitted to heating. An effective temperature control should be kept during honey de-crystallization stages, because a considerable HMF increase may occur when heating at $70^{\circ} \mathrm{C}$ as shown in the present study. After 720 minutes heating, the HMF content was $64.37 \mathrm{mg} / \mathrm{Kg}$, a value that exceeds the value allowed by the Brazilian law $(60 \mathrm{mg} / \mathrm{Kg})$
(BRASIL, 2000). Fallico et al. (2004), observed a significant increase of HMF content in eucalyptus honey subjected to $70^{\circ} \mathrm{C}$, for 96 hours, from an initial value below detection level to $513 \mathrm{mg} / \mathrm{Kg}$, in agreement with data obtained in the present study.

At high temperatures, such as 80 and $90^{\circ} \mathrm{C}$, a gradual increase was observed that significantly varied $(\mathrm{P}<0.01)$ with heating time, which was the factor that mostly influenced the increase of HMF content at these temperatures of samples that when heated at $90^{\circ} \mathrm{C}$ presented HMF levels of 29.55 and $66.96 \mathrm{mg} / \mathrm{Kg}$, after 60 and 180 minutes heat treatment, respectively. However, Turhan et al. (2008) presented different results. They reported low HMF contents in floral honeys subjected to 75 and $90^{\circ} \mathrm{C}$ heat treatments for up to 90 minutes. Those authors concluded that there was no significant increase of HMF in floral honeys heated at $90^{\circ} \mathrm{C}$ for up to 90 minutes, obtaining a maximum $\mathrm{HMF}$ content of only $11.24 \mathrm{mg} / \mathrm{Kg}$.

It should be enhanced that, at $100^{\circ} \mathrm{C}$, the formation of HMF presented a different behavior than at other temperatures, and, in this case, temperature was the factor that most significantly $(\mathrm{P}<0.01)$ influenced the increase of HMF, since there was an increase at all the times studied. In the same way, Turhan et al. (2008), described an increase of $\mathrm{HMF}$ content in floral honeys heated at $100^{\circ} \mathrm{C}$ for 30,45 , 60,75 and 90 minutes, from $0.62 \mathrm{mg} / \mathrm{Kg}$ in samples without heating to $13.99,26.4,37.98,55.41$ and $73.78 \mathrm{mg} / \mathrm{Kg}$, respectively. These authors observed a low HMF content in honeys subjected to heat treatments up to $90^{\circ} \mathrm{C}$, demonstrating that extreme heating significantly accelerates HMF formation.

Tosi et al. (2002) studied the effects of applying temperatures between 100 and $160^{\circ} \mathrm{C}$ in short time intervals, varying from 14 to $60 \mathrm{~s}$. The authors concluded that 
temperatures above $140^{\circ} \mathrm{C}$, even when applied during short time intervals, considerably increased HMF contents, which reached values above those recommended by international standards, demonstrating the influence of temperature on the increase of HMF content even in short time intervals. In the present study, we observed an increase of $\mathrm{HMF}$ content in samples submitted to heat treatment at $100^{\circ} \mathrm{C}$, regardless the heating time, significantly differing $(\mathrm{P}<0.05)$ at all levels, reinforcing the relevance of the study and in accordance with the above mentioned authors. After 60 minutes heating, HMF concentration was 48.19 $\mathrm{mg} / \mathrm{Kg}$, exceeding the limits recommended by the European legislation. Such increasing trend was maintained up to 720 minutes, when HMF concentration reached the highest levels, above $100 \mathrm{mg} / \mathrm{Kg}$.

The maximum value recommended by the Brazilian legislation of $60 \mathrm{mg} / \mathrm{Kg}$ (BRASIL, 2000), was not exceeded in the samples subjected to heating for 30,45 and 60 minutes, regardless the temperature used. However, increasing the time that the samples were kept in the thermostatic bath to 180 minutes, the samples exceeded the legal values at temperatures above $80^{\circ} \mathrm{C}$. It was also observed that samples heated for 180 minutes significantly differed $(\mathrm{P}<0.05)$ of samples heated for 720 minutes regardless the temperature used.

The samples heated during a 720 - minute period did not exceed the acceptable limit of $60 \mathrm{mg} / \mathrm{Kg}$, when the temperature was $70^{\circ} \mathrm{C}$ and, the samples submitted to $40^{\circ} \mathrm{C}$, presented an average $\mathrm{HMF}$ content of $27.15 \mathrm{mg} / \mathrm{Kg}$. Some authors observed that the increase of HMF is not related only to heating, and can occur during long storage periods, regardless the temperature. Khalil et al. (2010) studied HMF concentration in Malasian honeys stored during more than a year. They concluded that honey samples when stored during 12 to 24 months presented HMF concentrations that exceeded the recommended levels, reaching values of 118.47 and $1139.95 \mathrm{mg} / \mathrm{Kg}$, respectively. Kalábová et al. (2003) demonstrated that the content of HMF gradually increases during storage, eventually reaching values above those recommended by current legislation. Therefore, the time/temperature binomial used for honey processing should be as low as possible, considering that HMF increase may be influenced by factors other than exposure to adverse temperatures.

However, it is important to emphasize, that, in this study, honey was collected at Teresopolis municipality, a region characterized by altitude tropical climate, with cold, dry winters and template, humid summers, with annual average temperature of $16 \pm 2^{\circ} \mathrm{C}$ and relative humidity of the air of $84 \%$. Although the European legislation is more flexible with products from tropical regions, allowing contents of up to $80 \mathrm{mg} / \mathrm{Kg}$, the floral honey acquired for this study was not exposed to high temperatures in the hive, which explains the initial low content of HMF $(2.2 \mathrm{mg} /$ $\mathrm{Kg}$ ). Thus, we used $40 \mathrm{mg} / \mathrm{Kg}$ and $60 \mathrm{mg} / \mathrm{Kg}$, as references, the first is the value recommended by the Codex Alimentarius (CODEX, 1987) and the European Union Council (EUROPEAN COMMISSION, 2001) for honeys of non-tropical regions and the second the value recommended by the Brazilian legislation (BRASIL, 2000). These values are represented in figure 1, by grey and black horizontal lines.

\section{CONCLUSION}

HMF content significantly increases with the exposure to high temperatures during a long time. Considering the positive correlation between the thermal treatment and the increase of HMF content in fresh extracted honeys, it is suggested that HMF content is used as an indicator of honey quality loss caused by heating. Honeys with low initial HMF content may be submitted to temperatures up to $90^{\circ} \mathrm{C}$ for periods up to 60 minutes, for de-crystallization. However, for longer periods of time, up to 180 minutes, the temperature should not exceed $70^{\circ} \mathrm{C}$. Since honey overheating is not necessary for the filling process, mild temperatures should be used during limited times to reduce viscosity and prevent crystallization, without causing a significant increase of HMF content.

\section{REFERENCES}

AMES, J.M. The Maillard reaction. In B.J. F. HUDSON. Biochemistry of food proteins. London: Elsevier Science, 1992. p. 99-153.

ANAM, O.O; DART, R.K. Influence of metal ions on hydroxymethylfurfural formation in honey. Analytical Proceedings, United Kingdom, v.32, p. 515-517, 1995.

BATH, P.K.; SINGH, N. A comparison between Helianthus annuus and Eucalyptus lanceolatus honey. Food Chemistry, London, v.67, n.4, p.389-397, Dez. 1999.

BELITZ, H.D.; GROSCH, W. Food Chemistry. 2 ed. Berlin: Springer-Verlag, 1999, 992p.

BRASIL. Instrução normativa $\mathbf{n}^{\mathbf{0} 11}$, de 20 de outubro de 2000. Estabelece o Regulamento Técnico de Identidade e Qualidade do Mel. Brasília: Ministério da Agricultura Pecuária e Abastecimento, 2000. 
BRUCE, W.R.; et al. Diet, aberrant crypt foci and colorectal cancer. Mutation Research, USA, v. 290, n.1, p.111-118, Nov. 1993.

\section{CODEX STAN 12-1981 Rev. 1. CodexStandard for} Honey, 1987. Disponível em: < http://www.fao.org/ docrep/w0076e/w0076e30.htm>. Acesso em: $20 \mathrm{de}$ dezembro de 2011.

DAMODARAN, S.; PARKIN, K.L.; FENNEMA, O.R. Química de Alimentos de Fennema. 4. ed., Porto Alegre: Artmed, 2010, 900p.

EUROPEAN COMMISSION. Concil Directive 2001/110/ EC of 20 December 2001 relating to Honey, 2001. Disponível em: <http://ec.europa.eu/agriculture/markets/ honey/index_en.htm>.Acesso em: 17 de dezembro de 2011.

FALLICO, B. et al. Effects of conditioning on HMF content in unifloral honeys. Food Chemistry, London, v.85, n. 2, p.305-313, 2004.

JEANNE, F. La refonte du miel. Bulletin Technique Apicole, Polynesie Française, v.12. n.1, p. 33-40, 1985.

KALABOVA, K. et al. Hydroxymethylfurfural in Czech honeys. Czech Journal of Animal Science, Czech Republic, v.48, n. 12, p. 551-555, 2003.

KARABOURNIOTI, S; ZERVALAKI, P. The effect of heating on honey HMF and invertase. Apiacta, Romania, v.36, n.4, p. 177-181, 2001.

KHALIL, M.I.; SULAIMAN, S.A.; GAN S.H. High 5hydroxymethylfurfural concentrations are found in Malaysian honey samples stored for more than one year. Food and Chemical Toxicology, USA, v. 48, p.2388-2392, Ago./Set. 2010.

KROH, L.W. Caramelisation in food and beverages. Food Chemistry, London, v.51, n.4, p. 373-379, 1994.

LEE, H. S., NAGY, S. Relative reactivities of sugars in the formation of 5-hydroxymethyl furfural in sugar-catalyst model systems. Journal of Food Processing and Preservation, USA, v.14, n.3,p. 171-178, 1990.
NOZAL, M.J. et al. High-performance liquid chromatographic determination of methyl anthranilate, hydroxymethylfurfural and related compounds in honey. Journal of Chromatography A, United Kingdom, v. 917, n. 1-2,p. 95-103, Maio. 2001.

PIRO, R. et al. Conservazione del miele: cinetica di formazione Dell'idrossimetilfurfurale e di degradazione degli enzimi (diastasi e invertasi). Apicoltura Moderna, Italy, v.87, n.3, p. 105-114. 1996.

RAMIREZ, C.M.A.; GONZÁLEZ, N.S.A.; SAURI, D.E. Effect of the temporary thermic treatment of honey on variation of the quality of the same during storage. Apiacta, Romania, v.35, n.4, p. 162-170, 2000.

SANCHO, M.T. et al. Aging of honey. Journal of Agricultural and Food Chemistry, v.40, n.1, p.134-138. Jan.1992.

SPANO, N. et al. An RP-HPLC determination of 5hydroxymethylfurfural in honey: the case of strawberry tree honey. Talanta, v.68, n.4, p. 1390-1395, Fev. 2006.

SURH, Y.J. et al. 5-Sulfooxymethylfurfural as a possible ultimate mutagenic and carcinogenic metabolite of the Maillard reaction-product, 5-hydroxymethylfurfural. Carcinogenesis, Oxford, v.15, n.10, p. 2375-2377, Out. 1994.

TOSI, E. et al. Honey thermal treatment effects on hydroxymethylfurfural content. Food Chemistry, London, v.77, n.1, p.71-74, Maio. 2002.

TURHAN, I. et al. Quality of honeys influenced by thermal treatment. LWT - Food Science and Technology, Zurich, v. 41, n.8, p. 1396-1399, Set. 2008.

ULBRICHT, S.; NORTHUP, J.; THOMAS, A. Review of 5-hydroxymethylfurfural (HMF) in parenteral solutions. Fundamental and Applied Toxicology, Oxford, v. 4, n.5, p. 843-853, Out.1984.

WHITE, J.W. Spectrophotometric method for hydroxymethylfurfural in honey. Journal of the Association of Analytical Chemistry, USA, v. 62, n.3, 509-514, Maio. 1979. 